Portland State University

PDXScholar

Engineering and Technology Management

Faculty Publications and Presentations

$10-8-2018$

\title{
Genomics, Rare Diseases, and Disruptive Innovation in the Biopharmaceutical Industry
}

\author{
Mark J. Ahn \\ Portland State University \\ Amir Shaygan \\ Portland State University \\ Charles Weber \\ Portland State University, webercm@pdx.edu
}

Follow this and additional works at: https://pdxscholar.library.pdx.edu/etm_fac

Part of the Engineering Commons

Let us know how access to this document benefits you.

\section{Citation Details}

M. J. Ahn, A. Shaygan and C. Weber, "Genomics, Rare Diseases, and Disruptive Innovation in the Biopharmaceutical Industry," 2018 Portland International Conference on Management of Engineering and Technology (PICMET), Honolulu, HI, 2018, pp. 1-10.

This Article is brought to you for free and open access. It has been accepted for inclusion in Engineering and Technology Management Faculty Publications and Presentations by an authorized administrator of PDXScholar. Please contact us if we can make this document more accessible: pdxscholar@pdx.edu. 


\title{
Genomics, Rare Diseases, and Disruptive Innovation in the Biopharmaceutical Industry
}

\author{
Mark J. Ahn, Amir Shaygan, Charles Weber \\ Portland State University, Portland, OR - USA
}

\begin{abstract}
The multinational biopharmaceutical industry has to deal with significant financial pressures due to being a very costconstrained and highly regulated industry. To add to that, finite patent expirations on financially successful drugs, vying nature of the biotech industry due to new innovations. There has been an increase of smaller markets due to the proliferation of molecular segmentation patient populations in fields such as personalized medicine. Particularly, due to the significant cost reducing impacts of the development of "next-generation" sequence platforms on DNA sequencing in the last decade, molecular diagnostics are being considered as cost effective candidates to be used as a standard medical test, in terms of risk assessment, confirmation of diseases, and therapeutics. Biopharmaceutical companies need to reassess their drug development strategies and choose among alternative prospective business models in order to remain relevant amid the new innovations and developments. Using a dynamic capabilities lens, this paper tends to study the impact of genomics generally and gene therapy specifically on the rare disease sector of the biopharmaceutical industry by analyzing the public data from 24 genomics based rare disease focused biopharmaceutical companies. This study shows that growing rates of cumulative returns is dependent upon the accumulation of knowledge-based employees and expanding product portfolios of disruptive genomics-based technologies for treating rare diseases. Further, this study stresses the significance of structuring the capability and capacity to absorb expertise and accrue knowledge for new product innovations and viable competitive advantage.
\end{abstract}

\section{INTRODUCTION}

Multinational biopharmaceutical firms exist in an increasingly cost-constrained and highly regulated ecosystem. Concurrently, these companies have to cope with constant competitions which is imposed upon them due to their blockbuster drugs' expirations followed by the imminent emergence of generic drugs. They also exist in an environment which possesses a very high innovation rate and companies can lose their market monopoly due to new disruptive technologies. Moreover, in the last decade, there has be an escalation in the number of smaller markets due to the fall in the cost of DNA sequencing in result of the development of "next-generation" platforms and increase in genetic segmentation of patient populations. Molecular diagnostics in particular are now being considered as cost effective standard medical test options for assessing risk and diseases confirmations - and increasingly, as therapeutics for rare diseases as a result of DNA sequencing's affordability. Because of all these changes, it is imperative for biopharmaceutical companies to reassess their drug developments strategies and business models in order to stay relevant and competitive in this unforgiving market.
In the recent years there has been a paradigm shift in big multinational pharmaceutical companies' models. Companies like Merck, Pfizer, Roche, and Glaxo are no longer dismissing the rare disease market due to its small addressable market and targeted population. In contrast to the past, they are more interested in investing in rare disease treatments. Even some health systems are now focusing more on the importance of genetic predispositions and genomics related data as part of invigorating e delivery of care to the patients [1].

Currently, about $10 \%$ of Americans are dealing with approximately 7,000 rare diseases (only 5\% with approved treatments) [2,3]. Among a significant amount of technological breakthroughs in the recent years, one that has undoubtedly influenced the mentioned economic paradigm shift is the DNA sequencing which is the mapping of the human genome. The introduction of Sanger-based advances has caused the cost of sequencing a human-sized genome to plummet substantially from $\$ 100$ million to $\$ 1,000$ in the last three decades $[4,5]$. This new technology would mean substantially less amount of time needed for patient testing, higher government financial incentives, pediatric review voucher, and more approval rates from US Food and Drug Administration [6].

The genomics revolution is expected to disrupt traditional multinational pharmaceutical industry structure. In other words the sole focus is not going to be relying on large, chronic drug blockbusters targeted at large patient populations. Disruptive innovations such as gene therapy can deliver single treatment cures and can potentially shift the status quo in the biopharmaceutical industry structure. Amid these changes, biopharmaceutical companies are in great need to reprioritize drug development strategies and carefully choose among future business models options in order to stay competitive in a highvelocity market such as the biopharmaceutical industry. Using a dynamic capabilities lens, this proceeding aims to study the impacts of different financial, organizational, and productrelated resources on the enterprise value of genomics-based rare disease-focused biopharmaceutical companies. In order to pinpoint the influence of decreased cost and increased attraction in genomics generally and gene therapies specifically (delivery of single treatment cure using corrective genes for fatal rarediseases) on biopharmaceutical companies, the industry background and the influence of genomics in rare diseases are briefly studied. This study delves into capability and capacity building rare disease-focused biopharma companies. 


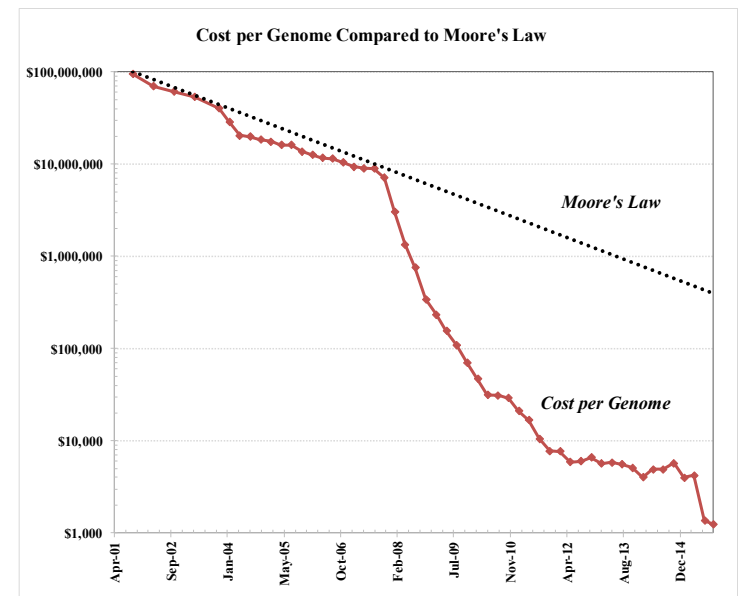

Figure 1. Cost per genome evolution compared to hypothetical data reflecting Moore's Law [5]

\section{THE BIOPHARMA INDUSTRY}

The biopharmaceutical industry is a mixture of traditional multinational drug manufacturers, biotechnology companies, and distribution companies mainly focused on medicinal and veterinary chemical and biological combinations. A pharmaceutical firm can be defined as company that performs commercial R\&D, marketing, and distribution of drugs [7]. Biotechnology is defined as techniques for changing microorganisms, and a biotechnology company focuses on manipulating living cells (plants or animals) using biological knowledge [8]. Pharmaceuticals and biotechnology organizations are placed in a highly dynamic industries with intense global competition, new product development (NPD) plays a significant role in reaching success in these types of companies [9]. Therefore, drug development companies have been shifting their strategies from manipulating natural compounds to use of new biologic understanding and tools in order to come up with new drug ideas and bolster their pipelines $[10,11]$.

New genomic insights and tools such as gene therapy, regenerative medicine and molecular diagnostics are causing significant industry paradigm shift from active disease confirmation to treatment decision-making, avoidance and wellness [12]. As one of the largest employers of scientists and one of the highest levels of R\&D among industries (increasing R\&D expenditure from $\$ 2.0$ billion in 1980 to $\$ 51.4$ billion in 2014 in US), the pharmaceuticals industry targets large global markets $[11,13]$. As an example, the United States possesses $86 \%$ of global biotech financing [14]. Some of the other traits of the biopharmaceutical industry are lengthy drug development wait times (10-12 years), low levels of successful drug transformation from clinical trials to approved drugs (less than 12\%), high drug development costs (from $\$ 179$ million in 1970 s to $\$ 2.6$ billion in 2000s-early 2010s), and high R\&D expenditure as fractions of sales $(23.4 \%$ and $17.9 \%$ for domestic and total sales respectively) $[15,16]$. An Ernest \& Young (2016) noted that 78 biotech companies offered their initial public offerings and raised $\$ 5.2$ billion in their IPOs, of which
45 were from US. Multinational biopharmaceutical companies are stressing the significance of strategic alliances in bolstering their pipelines (Ahn, et al., 2009; 2010).

One of the more disruptive sub-sectors of the biopharmaceutical industry is genomics which has an impact on different parts of the industry. An example of this are the companies that concentrate on single treatments for rare diseases. Therefore, many companies are significantly increasing $R \& D$ investment in genomics to penetrate the rare diseases market and take advantage of the new opportunities in treating unmet medical needs.

\section{A. Genomics in Rare Disease Treatment?}

Genomics is the scientific discipline of sequencing, mapping, and characterization of human genes. This breakthrough has had a significant impact on drug discovery and development in the biopharmaceutical industry $[17,18]$. Molecular genetics has significantly advanced drug development from risk assessment, early detection, and targeted therapies for needed medical shortages [19].

In the last 20 years, the cost of sequencing a human-sized genome has descended substantially from $\$ 100$ million to about $\$ 1,000$. Sequencing industry leader Illumina is aiming for a $\$ 100$ genome while focusing on accurate next generation sequencing (NGS) solutions, sequencing systems, and data analysis. The accelerated change of speed and the fall of per genome cost in the last decade reflects the shift from Sangerbased sequencing to next-generation genome sequencing technologies [4]. The rise of NGS technologies has enabled the generation of an enormous volume of data in a way more reasonable way (up to 1 billion short reads per instrument run) [20]. The information that genomics provides has the ability to improve our understanding of disease biology, personalized therapies and,in result, better health decision making through their combination with new technologies [21, 22].

The treatment of rare disease has been one of the biggest and most disruptive opportunities for the progress in genomics. Rare diseases provide researchers with smaller patient populations, and can enable the cost effective development of drugs for a non-homogeneous spectrum of diseases within a specific genetic disorder [23]. Rare disease is defined by the Rare Disease Act of 2002 as "any disease or condition that affects fewer than 200,000 people in the US" [24]. Genomics is facilitating researchers in better understanding the nature, severity, rate of progression, and clinical presentation of these diseases, many of which have impacts on pediatric populations. In a more pragmatic way for smaller biopharma companies, the increased interest in rare diseases is also provoked by smaller clinical trial populations, increased government financial incentives, and higher approval rates from US Food and Drug Administration (FDA). FDA Commissioner Scott Gottlieb noted that: "new guidance on the clinical evaluation of targeted therapies for rare disease subsets by the FDA...will address the issue of targeted drugs, and how we simplify the development of drugs targeted to rare disorders that are driven by genetic 
variations, and where diseases will all have a similar genetic fingerprint" [25].

As an example, Avexis, Inc. is developing AVXS-101 (gene therapy) for the treatment of Spinal Muscular Atrophy (SMA), which is uniformly fatal by 2 years of age [26]. This disease is caused by a single genetic defect and Avexis has the goal of alleviating or treating this disorder with the help of single treatment gene therapy. Initial results presented in 2017 demonstrated that 15 of $15(100 \%)$ patients were event-free at 13.6 months (versus an expected event-free survival rate based on the natural history of the disease of $25 \%$ ). Many companies such as Avexis, Biomarin, Bluebird, Abeona, Dimension, and Spark are targeting different debilitating, genetically-based rare diseases.

Many biotech firms embark on strategic alliances with larger firms to take advantage of the resources and attain validation [27]. Bluebird bio's partnership with Celgene; or Spark Therapeutics partnership with Pfizer in the development of SPK-9001 drug for the treatment of Hemophilia B are examples of this organizational behavior [28]. Moreover, some of these rare disease-focused biotech companies are co-located in biotech clusters such as New England and California which account for 17 of the 24 studied companies. Biotech clusters enhance access to academic research centers, qualified employees, experienced vendors and suppliers, informed life science venture investors, and shared resource arrangements $[29,30,11,31]$.

Ultimately, industry sectors rise by creating, building and capturing value. While the biotech sector has dramatically outperformed the S\&P 500 index (which represents the US stock market index based on the market capitalizations of 500 large companies having common stock listed on the NYSE or NASDAQ), the Rare Disease sub-sector of the biotech market has experienced extraordinary growth (Figure 2).

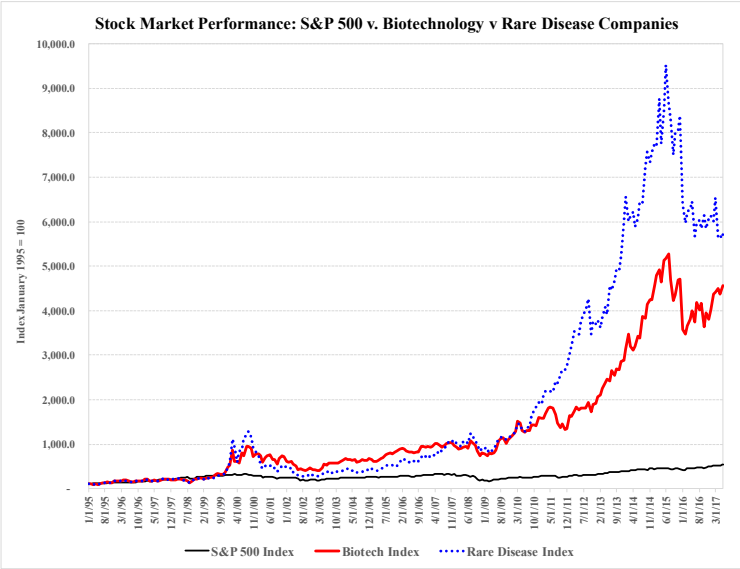

Figure 2: Stock Market Performance: S\&P 500 vs. Biotechnology v Rare Disease Companies

In conclusion, biopharmaceutical companies need to acquire dynamic capabilities in order to recognize, assimilate, transform, and exploit their tangible and intangible assets (tacit knowledge, R\&D know-how, NPD, alliances and acquisitions, and skilled workforce attraction) in order to accelerate innovation [32, 33]. Markets such as biopharmaceuticals are finely tuned to recognize and assess value, assess and manage risks and reward companies who innovate in targeted therapies $[34,31]$. The reason this study considers 24 companies is that there are currently 24 rare-disease focused, and genomics-based companies in the United States.

\section{DYNAMIC CAPABILITIES}

In the new technology-based era of NPD, faster information flow, and easier and faster access to markets, managing and orchestrating intangible assets are vital to building unique value and competitive advantage [35]. Teece, Pisano \& Shuen [36] suggest that competitive advantage is built and protected not in product markets but in markets for know-how and other intangibles which they refer to as the dynamic capabilities.

There are multiple definitions of dynamic capabilities in the literature. Pisano [37] defines them as organizational and strategic routines that allow managers to change, jettison, integrate, and re-connect resources in order to create new valuegenerating blueprints [38]. Dynamic capabilities are tools for generating, evolving, and morphing of resources to attain sustainable competitive advantage [36, 39]. By merging these definitions, [40] defines dynamic capabilities as the company's organizational and strategic actions to use, integrate, recombine, acquire and dispose of resources to equal or generate market change as a response to emergence, evolution, division, and demise of markets [41]. Some of these actions can be alliances, acquisitions, NPD, and strategic decision-making [42].

Moreover, Eisenhardt and Jeffrey [41] discuss multiple common characteristics between dynamic capabilities across high-tech organizations. Despite the fact that dynamic capabilities differ across various firms, some traits such as being "equi-final" (reaching dynamic capabilities from different roads and being path dependent); "compatible" (effectiveness of some capabilities across different industries); and "dependent on market animation and learning methods" can be common among technology-based companies [43, 41, 44]. In the context of the high velocity genomics-based biopharmaceutical markets, dynamic capabilities are dependent on the generation of new knowledge for increasingly specific patient populations. Moreover, firms with dynamic capabilities employ unique types of adaptive knowledge which can create activities as real-time information, prototyping, multi-criteria decision-making, and experimenting in an iterative and cognitive way, which leads to unpredictable outcomes [41].

Biopharmaceutical companies must adapt to fast-changing markets and rapid learning processes [45]. This environment necessitates the significance of learning from experience in order to create dynamic capabilities [46]. Studies demonstrate that the learning mechanism, rather than detailed a priori plans, plays an important part of the evolution of dynamic capabilities for firms. Repeated practices (in activities such as acquisitions, integration, and getting rid of resources) which lead to crucial gain of specific and tacit knowledge for firms [47, 48, 49]. What is more important about learned knowledge is the firm's ability 
to systemize, articulate, share, and embed the acquired knowledge into procedures and know-how as a way to a faster organizational learning $[48,41,65,58]$. Managers must acquire information from mistakes, failures and crises (real time and/or simulated scenarios) $[50,40,51]$.

Experience and speed can also improve the creation of dynamic capabilities through rapid acquisition of experience that can strengthen managers' decision-making ability, improve knowledge, and hone insights [48, 41]. Accumulation of experience in the selection and jettison of the products and businesses based on distinctive market changes is another important parts of dynamic capabilities vital for firms [46, 52]. Lastly, sequence appears to be important in generating dynamic capabilities [49, 41]. By assuming that dynamic capabilities as being modular and composed of smaller components (ingredients), the order of composition and implementation of smaller modules into a dynamic capability (recipe) is crucial for firms.

More recently, Pisano describes firm's capability problem as a problem being about selecting between different identification strategies for needed kind of capabilities. Each firm has to choose to either go deep or broad, general or market specific in terms of dynamic capabilities [53].

In sum, competitive advantage in high tech environments such as biopharmaceuticals is often episodic, fleeting and erratic. Hence, continual acquisition and rethinking of intangible assets and resources (sensing, seizing, and transforming) in order to generate and manage dynamic capabilities is vital to firms' success.

\section{Data Collection And Methodology}

As the next step, by considering the disruptive biopharma sub-sector of rare disease being directed by breakthroughs in genomics, we used the Biocentury database which tracks over 1,300 public and 4,000 private biotech companies worldwide from 1995-present with goal of finding elements of dynamic capabilities in building, creating and capturing value in the studied companies. We identified 24 publicly-traded rare disease-focused biotech companies, 18 of which focus exclusively on gene therapy, during the 1995-2017 period [25]. In the United States, a rare disease is defined as one that affects fewer than 200,000 people. According to the Genetic and Rare Diseases Information Center (GARD) at the National Institutes of Health, there are over 7,000 rare diseases with less than five percent having an approved treatment. The studied companies are primarily concentrated in biotech clusters located in Massachusetts and California (Figure 3).

Data were collected for each company in 11 categories (revenue, enterprise value, net income, retained earnings/ total financing, cash, number of employees, CEO tenure, number of board of director members, year of foundation, year of IPO, clinical/commercial products, and number of total products) on May $5^{\text {th }}, 2017$. The definition for each of these criteria is shown in Table 2. The enterprise value (EV) has been defined as follows:

$$
\begin{aligned}
\text { Enterprise Value }(\mathbf{E V}) & =\text { market value of common stock } \\
& + \text { market value of preferred equity } \\
& + \text { market value of debt } \\
& + \text { minority interest } \\
& - \text { cash and investments }
\end{aligned}
$$

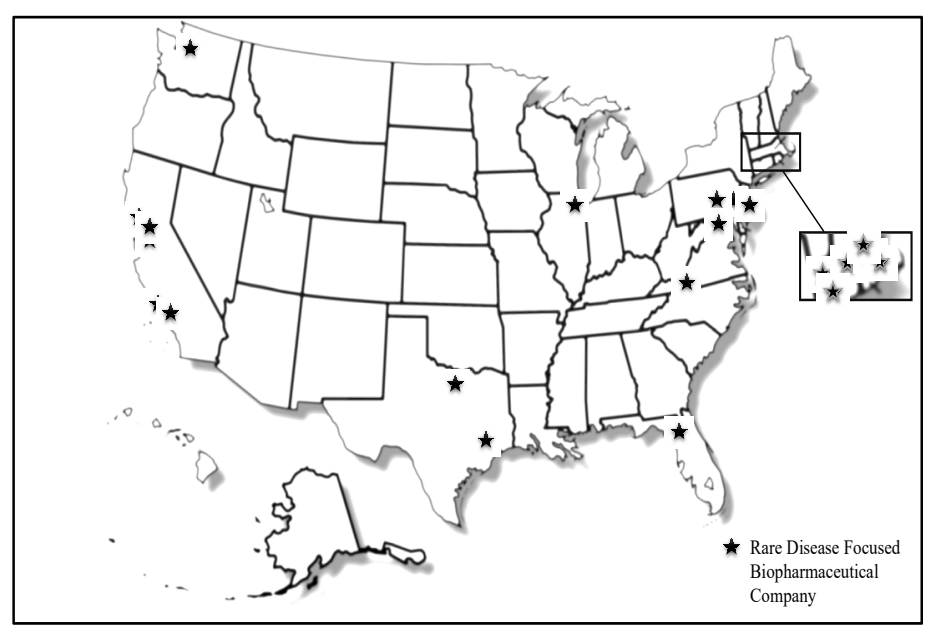

Figure 3. Geographical Locations of Rare Disease-based Companies

Where market capitalization is the total value of a

\begin{tabular}{|c|c|c|c|c|c|c|}
\hline & $N$ & Range & Ninimum & Naximum & Mean & Stc Deriation \\
\hline Entenprise Value (Nillion) & 24 & $\$ 27,816$ & $\$ 46$ & $\$ 27,770$ & $82,731.68$ & $\$ 6,199.31$ \\
\hline Reremue (Villion) & 24 & $\$ 3,011$ & so & $\$ 3,011$ & $\$ 2273.40$ & $\$ 681.68$ \\
\hline Net Income (Nillion) & 24 & $\$ 1,029$ & $\$ 630$ & $\$ 399$ & $\$ 11839$ & $\$ 175.98$ \\
\hline Retained Eanings(Million) & 24 & $\$ 2,984$ & $\$ 1,166$ & $\$ 1,818$ & .2277 .4 & $\$ 338.74$ \\
\hline Number of Employees & 24 & 2,909 & 15 & 2924 & 400.50 & 712.22 \\
\hline CEO Tenure & 23 & 14.5 & 0.5 & 15 & 477 & 4.15 \\
\hline Number of Board & 24 & 6 & s & 11 & 8 & 1.47 \\
\hline Yeas Foumded & 24 & 40 & 1974 & 2014 & 2002.04 & 10.96 \\
\hline PO Year & 24 & 20 & 1996 & 2016 & 2010.08 & 7.13 \\
\hline Clinical and Marketed & 24 & 13 & 0 & 13 & 4.08 & 3.48 \\
\hline Total Pipeline & 24 & 25 & 1 & 26 & 8.70 & 5.47 \\
\hline
\end{tabular}
company's balance sheet and total cash is the sum of all the cash that a firm has in its books [54]. Descriptive statistics for the collected 24 companies are shown in Table 1.

TABle 1: DesCriPTIVE STATISTICS For THE StUdied Companies

The drug development process is lengthy and risky, with development times of 7.5 to 19 years [55]. To determine the status of each company in terms of NPD, data from their drug pipelines were collected for discovery, preclinical, Phase 1-3, and commercialization. The feasibility, iterative testing, and safety-related information are collected during preclinical development. In the first phase of clinical trials new drug products or treatments are examined on a small number of subjects to assess safety and dosage. The second phase involves further evaluation of a drug's safety and efficacy by being tested 
on a larger population. In the third phase, the drug's effectiveness, side effects, and safety is examined on a larger, statistically significant group of patients versus an active control (e.g., placebo or current standard of care).

Each of these variables that are included in our statistical analysis fall under one of the three asset criteria. These criteria are finance-related, organizational related, and product related. The sub-criteria of each of these asset types can is shown in Table 3.

In order to assess the relationships between the enterprises value of the studied firms with these financial, organizational, and product attributes in the disruptive biopharma sub-sector of rare diseases, this study uses a multi-variate regression analysis.

TABLE 2. VARIABLE DEFINITIONS

\begin{tabular}{|c|c|}
\hline & Definition \\
\hline Enterprise Value & $\begin{array}{l}\text { The market capitalization of a company is simply its share price } \\
\text { multiplied by the number of shares a company has } \\
\text { outstanding. Enterprise value is calculated as the market capitalization } \\
\text { plus debt, minority interest and preferred shares, minus total cash and } \\
\text { cash equivalents. }\end{array}$ \\
\hline $\begin{array}{l}\text { Market } \\
\text { Capitalization }\end{array}$ & $\begin{array}{l}\text { The value of a company that is traded on the stock market, calculated by } \\
\text { multiplying the total number of shares by the present share price. }\end{array}$ \\
\hline Revenue & $\begin{array}{c}\text { Income, especially when of a company or organization and of a } \\
\text { substantial nature. }\end{array}$ \\
\hline Net Income & $\begin{array}{l}\text { Net income (NI) is a company's total earnings (or profit); net income is } \\
\text { calculated by taking revenues and subtracting the costs of doing business } \\
\text { such as depreciation, interest, taxes and other expenses. }\end{array}$ \\
\hline $\begin{array}{l}\text { Retained } \\
\text { Earnings }\end{array}$ & $\begin{array}{l}\text { Retained earnings refer to the percentage of net earnings not paid out as } \\
\text { dividends, but retained by the company to be reinvested in its core } \\
\text { business, or to pay debt. It is recorded under shareholders' equity on the } \\
\text { balance sheet. }\end{array}$ \\
\hline No of Employees & \# of Employees \\
\hline CE0 Tenure & Number of years since the last $\mathrm{CEO}$ change \\
\hline $\begin{array}{l}\text { No of Board } \\
\text { Members }\end{array}$ & Number of people in the board of directors \\
\hline Year Founded & Company establishment year \\
\hline IP0 & $\begin{array}{l}\text { An initial public offering (IPO) is the first time that the stock of a private } \\
\text { company is offered to the public. IPOs are often issued by smaller, } \\
\text { younger companies seeking capital to expand, but they can also be done } \\
\text { by large privately-owned companies looking to become publicly traded. }\end{array}$ \\
\hline $\begin{array}{l}\text { \# of Clinical and } \\
\text { Marketed } \\
\text { Products }\end{array}$ & Total number of products in phase $1,2,3$ and commercial \\
\hline $\begin{array}{l}\text { Total\# of } \\
\text { Products }\end{array}$ & $\begin{array}{l}\text { Total number of products in program area, discovery, } \\
\text { preclinical, phase 1-3, commercialized }\end{array}$ \\
\hline
\end{tabular}

TABLE 3. ASSET TYPES IN THIS STUDY

\begin{tabular}{c|c}
\hline Type of Asset & Sub-Criteria \\
\hline Finance Assets & $\begin{array}{c}\text { Revenue, net income, cash and retained } \\
\text { earnings }\end{array}$ \\
\hline Organizational Assets & $\begin{array}{c}\text { Number of employees, CEO tenure, and } \\
\text { number of the board of directors' } \\
\text { members, year of foundation, and year of } \\
\text { IPO }\end{array}$ \\
\hline Product Assets & $\begin{array}{c}\text { Number of products in various stages of } \\
\text { development }\end{array}$ \\
\hline \hline
\end{tabular}

The dependent variable 'Enterprise Value' is analyzed with regards to independent variables with respect to correlation (r), $\mathrm{p}$-value (p), and R-squared $\left(\mathrm{R}^{2}\right)$. Correlation is the degree which two metric variables are related in a linear manner. In this case, ( 0 to $(-) 0.3$ is considered as weak correlation; (-) 0.3 to (-) 0.5 is considered medium correlation; and (-) 0.5 to (-) 1.0 is considered as strong correlation. Negative correlations mean that an increase or decrease in the independent variable would result in the decrease or increase in the dependent value. The $\mathrm{p}$ value shows the significance $(\mathrm{p}<0.05)$ of the hypothesis. This means that if the p-value for each of the tests is $>0.05$ we reject the hypothesis (with $95 \%$ confidence). However, if the p-value is $<0.05$, we accept the hypothesis and consider the underlying assertion valid. Also, $\mathrm{R}^{2}$ refers to the percentage of 'Enterprise Value (EV)' that can be explained by different independent variables. In other words, $\mathrm{R}^{2}$ determines the proportion of the variance in EV that can be predicted using the tested independent variable. Finally, the non-standardized coefficient shows the amount of unit changes in the "Enterprise Value" with respect to changes in each independent variable. The results of regression tests and scatter plots are discussed next.

As initial step, the linear relationship between the independent variable (EV) and the dependent variables should be checked. For this purpose, scatter plots are used to determine if there is a good linear relationship between EV and different independent variables. Based on the linear R-square values, only the variables with medium or high ability to explain the variability of the response data around their mean were selected (Figure 4). As a result, revenue, retained earnings, number of employees, and total number of products were chosen for consideration. Cash was omitted from the analysis despite its higher R-square value due to the fact that it is a part of EV formula in order to avoid redundancy. Multivariate regression analysis (95\% confidence) was applied to the selected four criteria in order to study their potential effects on the EV of 24 rare-disease focused, genomics based companies in US. 

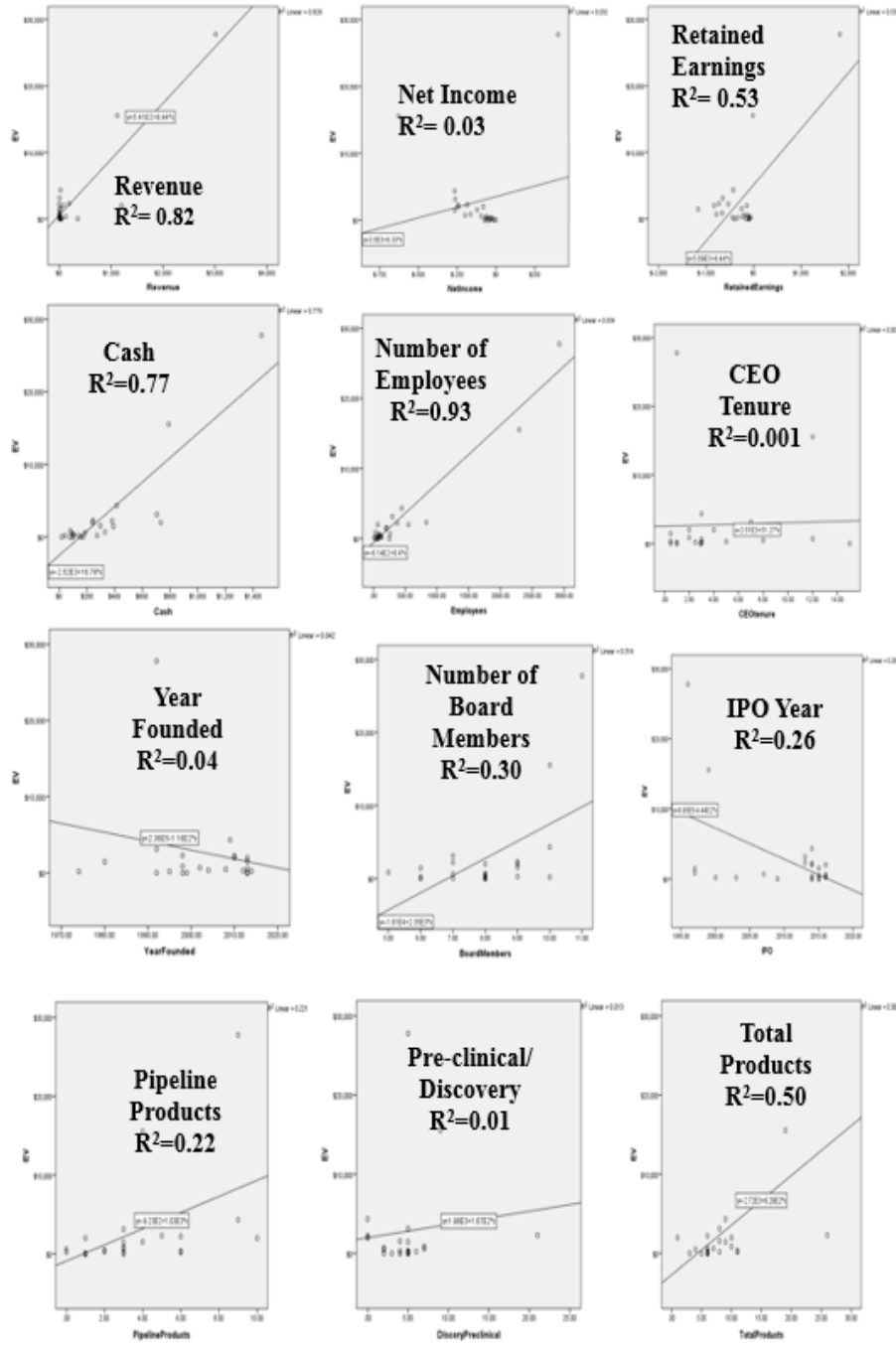

Figure 4: Scatter Plots for Independent Variables against EV

\section{RESULTS \& DISCUSSION}

The descriptive statistics for the variables that were analyzed with regards to their R-squared values in the previous step can be seen in Table 4. The results in Table 5 indicate that 'Revenue', 'Number of Employees', and 'Total Number of Products' have predictive power of 'Enterprise Value' for the studied rare disease companies. The four selected independent values account for explaining about 96\% (adjusted R-square) percent of EV value variances for the studied companies (Table 7). In this section, the adjusted R-square has been used in order to reflect the number of predictors in the model. The decrease in the adjusted R-square compared to the R-square shows that the predictor improves the model by less than expected by chance. The standardized coefficients in Table 5 also highlight the impact of number of employees on EV as the highest predictor.

Furthermore, number of employees and revenue were found to have significant correlations with the Enterprise Value at $96 \%$ and $91 \%$ respectively. Among the three variables that had significant p-values regarding $\mathrm{EV}$, number of products was the third correlated variable at $55 \%$ (Table 6).

Table 8 shows the F-test with the null hypothesis that the model explains zero variance in the $\mathrm{EV}\left(\mathrm{H}_{0}: \mathrm{R}^{2}=0\right)$. As the result of the F-test is highly significant, we reject the null hypothesis and can conclude that the model explains a significant amount of the variance in the studied companies' EV.

TABLE 4. Descriptive Statistics For ANALyZED VARIABLES

\begin{tabular}{|c|c|c|c|}
\cline { 2 - 4 } \multicolumn{1}{c|}{} & \multicolumn{3}{c|}{ Descriptive Statistics } \\
\cline { 2 - 4 } & Mean & Std. Deviation & $\mathrm{N}$ \\
\hline $\mathrm{EV}$ & $\$ 2,751.68$ & $\$ 6,199.315$ & 24 \\
\hline Revenue & $\$ 262.02$ & $\$ 669.037$ & 24 \\
\hline Retained Earnings & $-\$ 277.46$ & $\$ 538.745$ & 24 \\
\hline Employees & 400.5000 & 712.92520 & 24 \\
\hline Total Products & 8.7083 & 5.47309 & 24 \\
\hline
\end{tabular}

\begin{tabular}{|c|c|c|c|c|c|}
\hline \multicolumn{6}{|c|}{ Coefficients } \\
\hline \multirow{2}{*}{ Model } & \multirow{2}{*}{$\begin{array}{c}\text { Std Coeff } \\
\text { Beta }\end{array}$} & \multirow{2}{*}{$\mathrm{t}$} & \multirow{2}{*}{ Sig. } & \multicolumn{2}{|c|}{$\begin{array}{l}95.0 \% \text { Conf. Interval } \\
\text { for B }\end{array}$} \\
\hline & & & & LB & UB \\
\hline (Constant) & & 0.84 & 0.40 & -670.70 & 1576.65 \\
\hline Revenue & 0.21 & 2.34 & 0.03 & 0.21 & 3.84 \\
\hline $\begin{array}{l}\text { Retained } \\
\text { Earnings }\end{array}$ & 0.07 & 1.18 & 0.25 & -0.68 & 2.46 \\
\hline Employees & 0.78 & 7.95 & 0.00 & 5.02 & 8.61 \\
\hline $\begin{array}{c}\text { Total } \\
\text { Products }\end{array}$ & -0.07 & -1.21 & 0.04 & -224.36 & 59.38 \\
\hline
\end{tabular}

a. Dependent Variable: EV

TABLE 6. CORRELATIONS

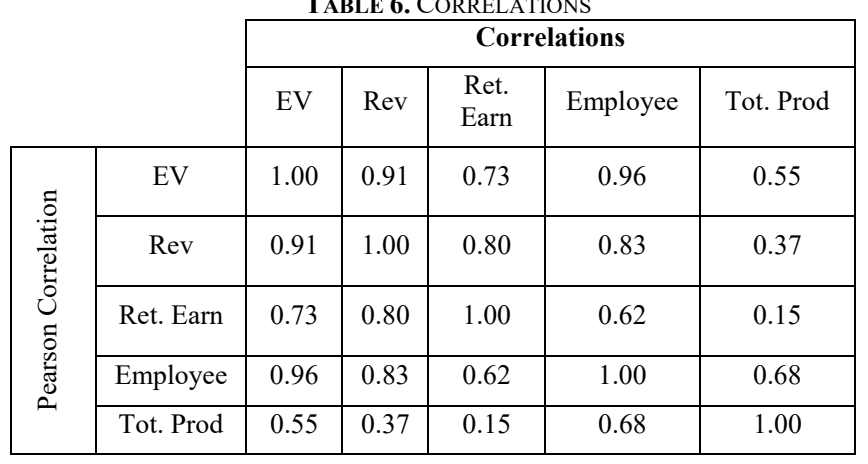

TABLe 7. MODEL SUMMARY

\begin{tabular}{|c|c|c|c|c|}
\hline Model & $\mathrm{R}$ & $\begin{array}{c}\mathrm{R} \\
\text { Square }\end{array}$ & $\begin{array}{c}\text { Adjusted } \\
\text { R Square }\end{array}$ & $\begin{array}{c}\text { Std. Error } \\
\text { of the } \\
\text { Estimate }\end{array}$ \\
\hline 1 & $.987^{\mathrm{a}}$ & 0.974 & 0.968 & $\$ 1,103.45$ \\
\hline
\end{tabular}

a. Predictors: (Constant), Total Products, Retained Earnings, Revenue, Employees

b. Dependent Variable: EV 
TABLE 8. ANOVA

\begin{tabular}{|c|c|c|c|c|c|}
\cline { 2 - 6 } \multicolumn{1}{c|}{} & \multicolumn{5}{c|}{ ANOVA } \\
\cline { 2 - 6 } \multicolumn{1}{c|}{} & Sum of Sq & df & Mean Sq & F & Sig. \\
\hline $\begin{array}{c}\text { Regressio } \\
\mathrm{n}\end{array}$ & 860790145.29 & 4 & 215197536 & 176.73 & $.000_{\mathrm{b}}$ \\
\hline Residual & 23134548.15 & 19 & 1217607 & & \\
\hline Total & 883924693.45 & 23 & & & \\
\hline
\end{tabular}

a. Dependent Variable: EV

b. Predictors: (Constant), Total Products, Retained Earnings, Revenue, Employees

Finally, the normality of the residuals were checked with a normal P-P plot in order to make sure that the points generally follow the normal line without any strong deviations. Figure 5 indicates that the residuals are normally distributed. The results were also checked for multicollinearity in the multi-variate regression model and all included independent variables were in the acceptable ranges (as shown in table 9) in terms of tolerance (above 0.1) and variance inflation factor (below 10). This shows that there is correlation between predictors (revenue, number of employees, retained earnings, and number of products).

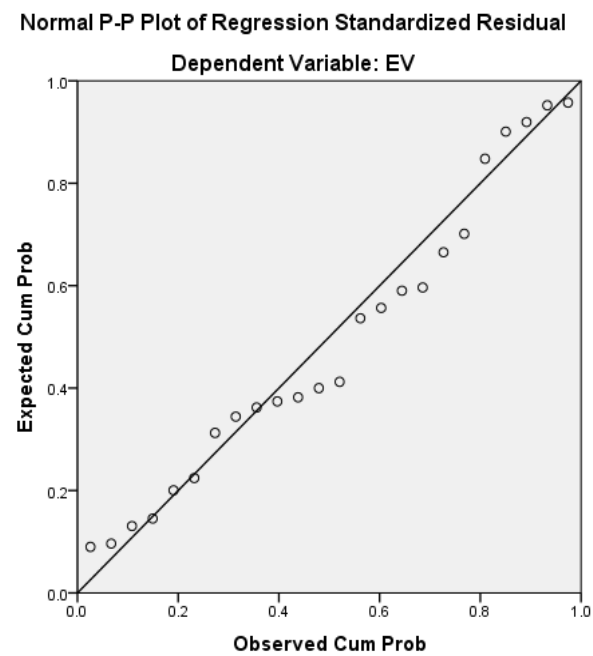

Figure 5. Normal P-P Plot of Regression Standardized Residual

\begin{tabular}{|c|c|c|}
\multicolumn{1}{c}{ TABLe 9.COLLInEARITY STATISTICS } \\
\cline { 2 - 3 } & \multicolumn{2}{c|}{ Collinearity Statistics } \\
\cline { 2 - 3 } & Tolerance & VIF \\
\hline Revenue & 0.157 & 6.351 \\
\hline Retained Earnings & 0.322 & 3.103 \\
\hline Employees & 0.142 & 7.066 \\
\hline Total Products & 0.385 & 2.600 \\
\hline
\end{tabular}

To conclude, the enterprise values in the rare disease focused, genomics based companies that were studied is correlated with number of employees, their revenues, and the number of products in the portfolios. These results can re-stress the importance of tangible and intangible assets and capabilities such as employee knowledge (tacit and explicit) and new product development which both have been identified as dynamic capabilities in the literature [56, 57, 9, 44, 41, 58].

\section{CONCLUSION}

Biopharma companies have to constantly deal with intense financial, competitive, regulative, technological, and market fluctuation pressures. Amid the high change rates, competitive advantage can be evasive and short-lived. Therefore, it is imperative for companies to constantly morph and manage their tangible and intangible assets and resources (i.e., sensing, seizing, transforming) in order to be successful and/or survive. Multiple examples of dynamic capabilities in technology-based firms stress the need to respond to market price changes, acquisition/forming alliances with goals of asset and organizational reconfiguration, product innovation for organizational renewal, and resource divestment $[59,60,61,62$, 63].

In order to earn these capabilities and add value, it is crucial for high-tech companies to attract expertise (i.e., employees in different levels of the organization such as researchers and board of director members) in order to guide company towards competitive advantage and commercial success. Furthermore, the aggregation of skilled and innovative employees lead to new product innovation and lead companies into a more flexible and efficient product pipeline. The knowledge and experience that the workforce can bring can be seen as a cumulative bolstering factor in leveraging dynamic capabilities which can be recognized, understood, and transformed in order to align with company goals and commercial success (i.e., increasing returns in enterprise value). In other words, technology managers' duty does not end on managing the finance-related criteria of the technology. Their duty also encapsulate management of human resources, asset configuration, and strategic alliances efficiently towards higher velocity and more efficient innovation. Strong dynamic capabilities can be formed with the accumulation of experience, articulation and codification of knowledge, and an adaptive ability to change the way they solve problems as the environment transforms [64]. In the case of biopharmaceutical companies, more efficient, prolific, and flexible employees can guide company to more successful NPD and a more efficient $\mathrm{R} \& \mathrm{D}$ pipeline.

The disruptive genomics transformation equips rare diseasebased biopharmaceutical companies with the opportunity to generate great value and shift the entire global industry from mass market to personalized medicine. Taking advantage of genomics and new technologies can direct biopharma firms to improve product innovation and boost their chances of attracting employee expertise, insightful boards of directors, and management teams. Biopharma managers should be alert in sensing the opportunities, threats, and resources followed by 
seizing and reconfiguring the acquired knowledge to fit their organization in order to gain and sustain competitive advantages.

In this study, twenty-four rare disease-focused biopharma companies were studied and several variables were tested with respect to enterprise value. The companies were analyzed as a group of rare disease firms. We found that variables such as number of employees, revenue, and number of products are correlated (in that order) with the enterprise value in rare disease-focused biopharma companies.

As an extension of this study, we would suggest comparing these results against the entire biotechnology industry as whole to better differentiate specialized rare disease companies. Furthermore, these variables can be analyzed based on the size of the companies (small, medium, and large cap). Individual linear regression can be implemented in order to take a deeper look into the relations of different variables compared to EV. Moreover, as number of employees was shown to be crucial to the $\mathrm{EV}$ values of the studied companies, further study into what kind of employees would have the most significant impact on biopharma companies might be insightful. Also, more research into the effects of the biopharma geographical clusters is intriguing as there is a definite geographical impact in terms of knowledge transfer and cross-pollination between firms in high velocity technological industries (as these areas employ more skilled employees and therefore accumulate more knowledge and enterprise value (shown as darker colored states) as shown in Figure 6).

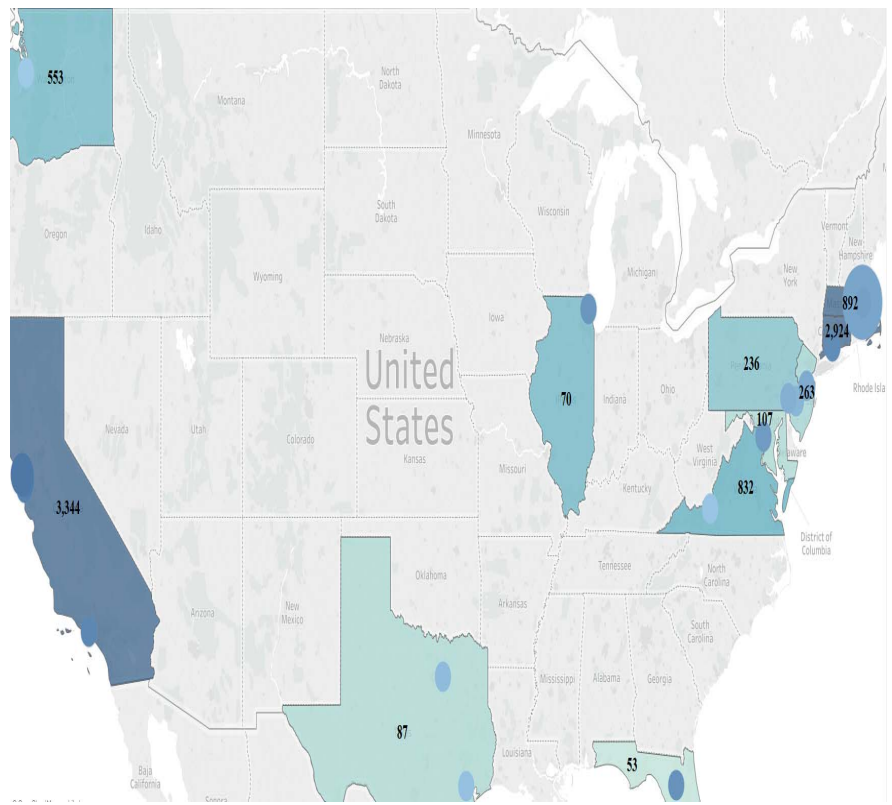

Figure 6. Active Geographical Clusters for Rare-disease Biopharma Companies and Respective Number of Employees

Using a dynamic capabilities lens, this paper studied the influence of genomics generally and gene therapy specifically on the rare disease sector of the biopharmaceutical industry. This study found that increasing rates of cumulative returns depends on accumulating knowledge-based employees and expanding product portfolios of disruptive genomics-based technologies for treating rare diseases. Also, this study stresses the significance of constructing the capability and capacity to attract expertise and accrue know-how for new product innovations and viable competitive advantage. The findings of this paper highlight the influence of decreased cost and increased attraction in prospective prevalence of genomics and its position as a disruptive innovation with impact on the biotech industry.

\section{REFERENCES}

[1] A. Shaygan, "Landscape Analysis: What Are the Forefronts of Change in the US Hospitals?," in Infrastructure and Technology Management, Springer, Cham, 2018213-243.

[2] M. J. Piccart-Gebhart, "The 41st David A. Karnofsky memorial award lecture: academic research worldwide-quo vadis?," Journal of Clinical Oncology, vol. 4, no. 32, pp. 347-354, 2013.

[3] Medicines in Development, "Medicines in Development for Rare Diseases: A report on orphan drugs in the pipeline," Pharmaceutical Research and Manufacturers of America, 2016.

[4] E. R. Mardis, "The impact of next-generation sequencing technology on genetics," Trends in genetics, vol. 3, no. 24, pp. 133-141, 2008.

[5] K. Wetterstrand, "DNA Sequencing Costs: Data from the NHGRI Genome Sequencing Program (GSP)," National Human Genome Research Institute, NIH, 2016.

[6] FDA, "Fast Track, Breakthrough Therapy, Accelerated Approval, Priority Review," 149 2015. [Online]. Available: https://www.fda.gov/ForPatients/Approvals/Fast/ucm20041766.htm. [Accessed 26 2017].

[7] J. L. McGuire, h. Hasskarl, G. Bode, I. Klingmann and M. Zahn, Pharmaceuticals, general survey, Ullmann's Encyclopedia of Industrial Chemistry, 2007.

[8] W. Shan, G. Walker and B. Kogut, "Interfirm cooperation and startup innovation in the biotechnology industry," Strategic management journal, vol. 15.5, pp. 387-394, 1994.

[9] D. L. Deeds, D. DeCarolis and J. Coombs, "Dynamic capabilities and new product development in high technology ventures: An empirical analysis of new biotechnology firms," Journal of Business venturing, vol. 15 , no. 3, pp. 211-229, 2000.

[10] S. Casper and C. Matraves, "Institutional frameworks and innovation in the German and UK pharmaceutical industry," Research Policy, vol. 32.10, pp. 1865-1879, 2003.

[11] M. J. Ahn, M. Meeks, S. Davenport and R. Bednarek, "Exploring technology agglomeration patterns for multinational pharmaceutical and biotechnology firms," Journal of Commercial Biotechnology, vol. 16, no. 1, pp. 17-32, 2010.

[12] Biotechnology Industry Organization, "BIO 2005-2006: Guide to Biotechnology," Biotechnology Industry Organization, Washington, 2006.

[13] PhRMA, "Pharmaceutical Research and Manufacturers of America (PhRMA) annual membership survey," Washington,DC, 2015.

[14] Ernst and Young, "Beyond Borders 2016: Biotech Financing- Boutiful harvest leaves biotech well prepared for financial winter," Ernst and Young, 2016.

[15] PhRMA, "Biopharmaceutical Reasearch Industry: 2015 Profile," PhRMA, 2015.

[16] J. A. Dimasi, "Cost of Developing a New Drug :R\&D Cost Study Briefing," Tufts Center for the Study of Drug Develepoment , Boston, MA, November 18, 2014.

[17] G. Emilen, M. Ponchon, C. Caldas, O. Isacson and J. M. Maloteaux, "Impact of genomics on drug discovery and clinical medicine," Qjm, vol. ;93(7), pp. 391-423, 2000. 
[18] J. Venter, Adams, W. M. Myers, P. w. Li, R. J. Mural, G. G. Sutton and H. Smith, "The sequence of the human genome," science, vol. 291.5507, pp. 1304-1351, 2001.

[19] M. J. Khoury, S. B. CLayser, A. N. Freedman, E. M. Gillanders, R. E. Glasgow, W. M. Klein and S. D. Schully, "Population sciences, translational research, and the opportunities and challenges for genomics to reduce the burden of cancer in the 21 st century," Cancer Epidemiology and Prevention Biomarkers, vol. 20.10 , pp. 2105-2114, 2011.

[20] M. L. Metzker, "Sequencing technologies - the next generation," Nature reviews genetics, vol. 11.1, pp. 31-46, 2010.

[21] E. D. Green and M. S. Guyer, "Charting a course for genomic medicine from base pairs to bedside," Nature, vol. 470(7333), pp. 204-213, 2011.

[22] K. A. Calzone, J. A. Jenkins, N. Nicol, H. Skirton, W. G. Feero and E. D. Green, "Relevance of genomics to healthcare and nursing practice.," Journal of Nursing Scholarship, vol. 45, no. 1, pp. 1-2, 2013.

[23] A. Pariser, "Rare Disease and Clinical Trials," Office of Translational Sciences. Center for Drug Evaluation and Research. FDA, 2014.

[24] 107th US Congress, "Rare Diseases Act of 2002 (Public Law 280)," 107th United States Congress, 2002.

[25] Biocentury, "FDA Launchin Innovation Plan," Biocentury (Steve Usdin), 2017.

[26] A. p. d. Q. Campos Araujo, M. Arauajo and K. J. Swoboda, "Vascular Perfusion Abnormalities in Infants with Spinal Muscular Atrophy," The Journal of Pediatrics, vol. 155, no. 2, pp. 29-294, 2009.

[27] M. J. Ahn, A. S. York and P. Rizova, "Pathways to biomedical tipping points: Vertical, horizontal or other?," Journal of Commercial Biotechnology, vol. 16.3 , pp. 224-238, 2010.

[28] L. M. Draper, M. L. Kwoong, S. Stevanovic, E. Tran, S. Kerkar, M. Raffeld, S. A. Rosenerg and C. S. Hinrichs, "Targeting of HPV-16+ Epithelial Cancer Cells by TCR Gene Engineered T Cells Directed against E6.," Clinical Cancer Research, vol. 21, no. 19, pp. 4431-4439, 2015.

[29] D. M. DeCarolis and D. L. Deeds, "The impact of stocks and flows of organizational knowledge on firm performance: An empirical investigation of the biotechnology industry," Strategic management journal, pp. 353-368, 1999.

[30] M. J. Ahn, M. D. Meeks, S. Davenport and R. Bednarek, "Death of distance? - biotechnology agglomeration patterns, alliance proximity, and firm performance," International Journal of Innovation and Technology Management, vol. 6.03, pp. 247-264, 2009.

[31] Z. Al-Khateeb, N. Hadker and J. G. Scaife, "What We Value: The Proposition Behind the Price," Trinity Partners, Waltham,MA, 2016.

[32] D. J. Collis, "'Research note: how valuable are organizational capabilities?," Strategic management journal 15.S1, pp. 143-152, 1994.

[33] S. A. Zahra and G. George, "Absorptive Capacity: A Review, Reconceptualization, and Extension," The Academy of Management Review, vol. 27, no. 2, pp. 185-203, 2002.

[34] M. J. Ahn and M. Meeks, "Building a conducive environment for life science-based entrepreneurship and industry clusters," Journal of Commercial Biotechnology, vol. 14.1, pp. 20-30, 2008.

[35] D. J. Teece, "Capturing value from knowledge assets: The new economy, markets for know-how, and intangible assets," alifornia management review, vol. 40.3, pp. 55-79, 1998.

[36] D. Teece, G. Pisano and A. Shuen, "Dynamic capabilities and strategic managemt," strategic managemt Journal, vol. 7, no. 18, pp. 509-533, 1997.

[37] G. Pisano, "Knowledge, integration, and the locus of learning: an empirical analysis of process developement," Strategic Management Journal, vol. Winter Special 15, pp. 85-100, 1994.

[38] R. Grant, "Toward a knowledge-based theory of the firm," Strategic Management Journal, vol. 17, no. Summer Special Issue, pp. 109-122, 1996.
[39] R. Henderson and I. Cockburn, "Measuring com- petence? Exploring firm effects in pharmaceutical research.," Strategic Management Journal, no. Winter Special Issue 15, pp. 63-84., 1994.

[40] K. Eisenhardt and D. Sull, "What is strategy in the new economy?," Harvard Business Review, vol. 79.1, pp. 106-117, 2001.

[41] K. M. Eisenhardt and M. A. Jeffrey, "Dynamic capabilities: what are they?," Strategic management journal, vol. Vol. 21, no. Special Issue: The Evolution ofFirm Capabilities, pp. 1105-1121, 2000.

[42] M. J. Ahn, A. S. York, S. Y. Sohn and P. Benyamini, "Biotechnology Innovation: A Legitimacy-Based View," International Journal of Innovation and Technology Management, vol. 10.04, 2013.

[43] M. Zollo and S. G. Winter, From organizational routines to dynamic capabilities, INSEAD, 1999.

[44] S. Winter, "Understanding dynamic capabilities," Strategic management journal, vol. 24(10), pp. pp.991-995, 2003.

[45] A. S. York, L. M. Dunham and M. J. Ahn, "Vertical versus horizontal integration in the biopharma industry: the link between acquisition announcements and stock market performance," in Advances in Mergers and Acquisitions, C. L. Cooper and S. Finklestein, Eds., Emerald Group Publishing Limited, 2012, pp. 121-143.

[46] C. Gersick, "Pacing strategic change: the case of a new venture," Academy of Management Journal, vol. 37(1), pp. 9-45, 1994.

[47] M. Zollo and H. Singh, "The impact of knowledge codification, experience trajectories and integration strategies on the performance of corporate acquisition," in Academy of Management, San Diego, CA, 1998.

[48] L. Argote , Organizational Learning: Creating, Retaining, and Transferring Knowledge. K, Boston, MA: Kluwer Academic, 1999.

[49] S. L. Brown and K. M. Eisendhardt, "The art of continuous change: linking complexity theory and time-paced evolution in relentlessly shifting," Administrative Science Quarterly, vol. 42(1), pp. 1-34, 1997.

[50] L. Kim, "Crisis construction and organizational learning," Organization Science, vol. 9(4):, pp. 506-521, 1998.

[51] I. Barreto, "Dynamic capabilities: A review of past research and an agenda for the future," Journal of management, vol. 36.1, pp. 256-280, 2010.

[52] M. A. Sastry, "Managing strategic innovation and change," Administrative Science Quarterly, vol. 44(2):, pp. 420-422., 1999.

[53] G. Pisano, "Toward a prescriptive theory of dynamic capabilities: connecting strategic choice, learning, and competition.," Industrial and Corporate Change, vol. 26.5 , pp. 747-762, 2017.

[54] T. Koller, M. Goedhart and D. Wessels, Valuation: Measuring and Managing the Value of Companies, Fifth Edition ed., John Wiley \& Sons, 2010.

[55] J. A. Dimasi, R. A. Hansen and H. G. Grabowski, "The Price of Innovation: New Estimates of Drug Development Costs," Journal of Health Economics, vol. 22, pp. 151-185, 2003.

[56] C. Collins and K. Smith, "Knowledge exchange and combination: The role of human resource practices in the performance of hightechnology firms.," Academy of management journal, vol. 49.3, pp. 544-560, 2006.

[57] R. Grant, "Prospering in dynamically-competitive environments: Organizational capability as knowledge integration.," Organization science, vol. 7.4, pp. 375-387, 1996.

[58] M. Zollo and S. Winter, "Deliberate learning and the evolution of dynamic capabilities," Organization science, vol. 13(3), pp. pp.339$351,2002$.

[59] C. E. Helfat, "Know-how and asset complementarity and dynamic capability accumulation: The case of R\&D," Strategic management journal, pp. 339-360., 1997.

[60] S. Karim and W. Mitchel, "Path-dependent and path-breaking change: Reconfiguring business resources following acquisitions in the US medical sector, 1978-1995," Strategic management journal, pp. 1061$1081,2000$. 
[61] E. Danneels, "he dynamics of product innovation and firm competences," Strategic management journa, vol. 23.12, pp. 10951121, 2002.

[62] T. P. Moliterno and M. F. Wiersma, "irm performance, rent appropriation, and the strategic resource divestment capability," Strategic Management Journal, vol. 28.11, pp. 1065-1087, 2007.

[63] V. Ambrosini and C. Bowman, "What are dynamic capabilities and are they a useful construct in strategic management?," International journal of management reviews, vol. 11.1, pp. 29-49, 2009.

[64] S. A. Zahra and H. J. Sapienza, "Entrepreneurship and dynamic capabilities: A review, model and research agenda.," Journal of Management studies, vol. 43(4), pp. 917-955, 2006.
[65] P. Kale, J. H. Dyer and H. Singh, "Alliance capability, stock market response, and long-term alliance success: the role of the alliance function," Strategic Management Journal 23.8, pp. 747-767, 2002.

[66] S. D. Kahn, "On the Future of Genomic Data," Science, Vols. 331 (6018),doi: 10.1126/science.1197891, pp. 728-729, 2011.

[67] J. S. Reis-Filho, "Next-generation sequencing," Breast Cancer Research, vol. 11.3, p. S12, 2009.

[68] Biomarin, "Pipeline," Biomarin, 2Q17. [Online]. Available: http://www.biomarin.com/products/pipeline. [Accessed 26 2017].

[69] Investopedia, "Market Capitalization," Investopedia, [Online]. Available:

http://www.investopedia.com/terms/m/marketcapitalization.asp?ad=di $\mathrm{rN} \& \mathrm{qo}=$ investopediaSiteSearch $\& \mathrm{qsrc}=0 \& \mathrm{o}=40186$. [Accessed 285 2017]. 